Abstracta Iranica Abstranica

Revue bibliographique pour le domaine irano-aryen

Volume 29 | 2008

Comptes rendus des publications de 2006

\title{
Distant Relations. Iran and Lebanon in the last 500 years. Londres - New York, I. B. Tauris, 2006, 322 p.
}

\section{Clément Therme}

\section{(2) OpenEdition}

1 Journals

\section{Édition électronique}

URL : http://journals.openedition.org/abstractairanica/27222

DOI : 10.4000/abstractairanica. 27222

ISSN : 1961-960X

Éditeur :

CNRS (UMR 7528 Mondes iraniens et indiens), Éditions de l'IFRI

\section{Édition imprimée}

Date de publication : 15 mai 2008

ISSN : 0240-8910

\section{Référence électronique}

Clément Therme, "Distant Relations. Iran and Lebanon in the last 500 years. Londres - New York, I. B. Tauris, 2006, 322 p. », Abstracta Iranica [En ligne], Volume 29 | 2008, document 137, mis en ligne le 15 septembre 2008, consulté le 26 septembre 2020. URL : http://journals.openedition.org/ abstractairanica/27222 ; DOI : https://doi.org/10.4000/abstractairanica.27222

Ce document a été généré automatiquement le 26 septembre 2020.

Tous droits réservés 
Distant Relations. Iran and Lebanon in the last 500 years. Londres - New York, I. B. Tauris, 2006, 322 p.

Clément Therme 
1 Cet ouvrage collectif permet d'envisager les relations irano-libanaises sur un temps long et d'aller au-delà de l'approche médiatique qui se limite le plus souvent à l'étude de la connexion République islamique / Hezbollah. En se focalisant sur les liens transnationaux, qu'ils soient culturels, religieux, commerciaux ou sécuritaires ou qu'ils concernent la formation des élites iraniennes au Liban, les auteurs nous permettent de comprendre en profondeur ces relations complexes qui ont été plus souvent amicales que conflictuelles. Le principal apport de ce livre est de mettre en évidence les différents moments historiques des rencontres irano-libanaises et les influences réciproques qui en ont découlé.

L'ouvrage débute par une introduction signée de H. E. Chehabi et Hassan I. Mneimneh : «Five centuries of Lebanese-Iranian encounters ». La première partie, Iran and

Pre-Independence Lebanon contient les articles suivants : Albert Hourani : « From Jabal 'Amil to Persia »; Rula Jurdi Abisaab : « History and self-image: the 'Amili ulema in Syria and Iran (Fourteenth to Sixteenth Centuries) " ; Richard Hollinger : " An Iranian Enclave in Beirut: Baha'I Students at the American University of Beirut, 1906-1948 » ; H. E. Chehabi : " An Iranian in First World War Beirut: Qasem Ghani's reminiscences ». Dans la seconde partie, Pahlavi Iran and the First Republic, on trouve : H. E. Chehabi and Majid Tafreshi : «Musa Sadr and Iran »; W. A. Samii : "The security relationship between Lebanon and pre-revolutionary Iran »; H. E. Chehabi : « The anti-shah opposition and Lebanon ». Enfin, dans la troisième partie, The Islamic Republic and Hizbullah : H. E. Chehabi : "Iran and Lebanon in the revolutionary decade »; Rula Jurdi Abisaab : «The cleric as organic intellectual: revolutionary shi'ism in the Lebanese Hawzas "; Judith Harik : " Hizbullah's public and social services and Iran »; H. E. Chehabi : «Iran and Lebanon after Khomeini ».

\section{INDEX}

Thèmes : 4.0. Généralités

\section{AUTEURS}

\section{CLÉMENT THERME}

IFRI - Téhéran 